\title{
Urban activity spaces: the case of a post-Soviet neighbourhood in Riga
}

\author{
M. Ušča \\ The University of Latvia, Latvia
}

\begin{abstract}
Neighbourhood activity spaces have been the subject of a significant amount of research and evaluation in Western Europe and the US. However, it is predictable that the situation in the neighbourhoods of Eastern Europe is different, especially in regard to those built during the Soviet era. Beginning with the assumption that the city planning ideas and ideals of the communist period are still present in urban space, the author explores daily activity spaces and attitudes of inhabitants towards them in the neighbourhood of Mezciems, which was planned and built during the Soviet era in the city of Riga, the capital of Latvia. In order to find out the ways the inhabitants perceive and use the space in a post-Soviet neighbourhood, as well as the ways in which they make the neighbourhood more liveable for themselves, the author uses semi-structured indepth interviews with, and maps drawn by long-standing residents of the Mezciems neighbourhood. The results show that it is possible to mark out two lifestyles of long-standing residents during the Soviet era neighbourhood, characterized by different attitudes towards the functions available in the postSoviet neighbourhood. At the same time, the spaces used, as well as the ideas about improvements that would make the post-Soviet neighbourhood space more enjoyable for them are quite similar within these two groups of people, characterized by different lifestyles.
\end{abstract}

Keywords: urban activities, urban space, post-Soviet neighbourhood, Riga.

\section{Introduction}

Neighbourhood activity spaces have been the subject of a significant amount of research and evaluation in Western Europe and the US (e.g., [1-5]). However, it is predictable, that the situation in the neighbourhoods of Eastern Europe, 
especially in regard to those built during the Soviet era during the Soviet era, is different because of Soviet economic and physical planning policy.

Although, there are a notable amount of studies regarding Soviet town and housing planning policy [6-8] as well as different aspects of neighbourhoods in post-Soviet cities, e.g., the sense of neighbourhood [9], segregation [10] and crime $[11,12]$, not many (or any) studies have been conducted regarding Soviet micro-district or micro-neighbourhood planning and activity spaces in them during the post-Soviet period. Therefore, the aim of this project was to empirically investigate the outgrowth of micro-neighbourhood planning policy; in particular, to investigate the planning ideas for micro-neighbourhoods which were intended to be ideal dwelling areas during the Soviet era and their outcome as seen nowadays in post- Soviet neighbourhoods. In order to find out how Soviet era micro-neighbourhoods function today, daily activity spaces and attitudes of residents towards them were explored in the neighbourhood of Mezciems, which was planned and built during the Soviet era in the city of Riga, the capital of Latvia.

\section{The ideas and ideals of Soviet neighbourhood - the planning of micro-neighbourhoods}

Micro-neighbourhoods (or as called in Soviet Union - microrayons) were the basic residential units in Soviet town planning incorporating residential buildings as well as health, educational, cultural, sports and retail services. Microneighbourhoods were usually planned for 5,000-15,000 [14: 75] residents, depending upon the size of the city. As "one of the basic goals of Soviet national urban policy for decades was to limit the growth of large cities" [15: 264] and the Soviet housing policy sought to find the type of housing construction and density which minimised costs to the government [14], the residential houses in micro-neighbourhoods were usually 5 to 16 storey block buildings that ensured high density of residents in these areas.

Another instrument that set the permissible size of a micro-neighbourhood as well as the amount, location and configuration of housing, manufacturing and community facilities was construction standards - Construction Norms and Regulations (SNiP) [15] that were common throughout the Soviet Union and were based mainly on German standards [16]. In accordance with the SNiP, a specific amount of functions had to be provided for a concrete number of people - there was a precisely set number/square metres/places in a hall per 1,000 residents, e.g., there had to be a cinema with 10 places per 1,000 residents in a micro-neighbourhood [17]. Thus, micro-neighbourhoods were planned to be self-sufficient territories with their own maintenance and residents.

Usually, residential areas were built after development of a specific and complicated detail plan. These areas were developed either based on existing urban territories by partly or fully changing the street network and natural landscape or built in pristine areas with all the necessary infrastructure and communications. 
Although the available functions in micro-neighbourhoods were intended to be varied, the environment of these areas turned out to be similar and homogeneous due to the standardized residential block houses common throughout the Soviet Union. Starting from 1960's right through to the collapse of the Soviet Union, a programme to produce as many square metres of housing as possible was carried out. The building designs were prepared in central institutes and "the current models distinguished by numbers were built from Murmansk to Baku, from Vladivostok to Riga" [13]. The series of residential block buildings were the same in the Soviet Union, but the projects were adapted to the specific territory by taking into account the geographical location climate, and the available construction materials which slightly differed from republic to republic [16].

\section{Methodology}

In the case study of Mezciems district, a couple of methods were used. Firstly, in order to find out the historical perspective of the planning of Mezciems, cartographic material (the detail plan of Mezciems) and documents (SNiP) were analyzed. Secondly, in order to find out the spaces used and activities carried out by residents of Mezciems, as well as their attitude towards the space, two methods were used: interviewing and mapping. 10 semi-structured in-depth interviews with long standing residents of Mezciems (at least 5 years living in Mezciems) were carried out in September - October 2009. The respondents were asked to comment not only upon their own activities and spaces they use in their residential area, but also to provide their observations about other residents.

Mapping was used to get data that helped to understand the daily space of each respondent and enabled the use of spatial analyses, as well as visually depiction of the result. The attitude of residents towards the space was investigated through their experience of spending time there. The sampling of respondents was stratified along two dimensions - place and length of residence. In October-November 2009, 15 long standing residents of Mezciems were given a map and asked to colour in spaces they use for their daily activities. The territory of Mezciems and the names of the main streets were placed on the map to help to guide the respondent. In order to reflect not only the spaces the respondents use, but also their attitude, they were asked to use:

1. the colour green for marking the territories in which they feel good which they use willingly;

2. the colour yellow for marking the territories towards which they do not have any particular feeling;

3. the colour red for marking the territories in which they do not feel safe territories which they would like to avoid;

4. not to colour territories which they do not use for their daily activities;

5. to mark their place of residence.

The maps, coloured in by residents of Mezciems, were transformed into digital maps using ArcView - a Geographic Information System software that enables the performance of manipulations and analysis of maps. In ArcView, 
maps are stored as a combination of identical pixels. Due to the colours, used by the respondent for a specific territory, each pixel is given a numeric value: -1 for red; 0 for yellow and +1 for green. In this way all maps become numeric matrices. And it becomes possible to sum up all the coloured areas. The result shows the attitude of residents towards the specific territory - higher sum means that more respondents have coloured in this territory as a good and safe one and vice versa.

\section{The development of Mezciems micro-neighbourhood}

The construction of multi-storey block buildings in Latvia started at the end of 1950 's and was in progress in large quantities until the early 1990's. During this period about $40 \%$ of the current area of housing stock was built, from which the largest part constitutes large scale block buildings [18]. At the end of the 1950's, the process of industrialization gathered pace in Latvia and as a result the number of residents in Riga increased rapidly - from 226,000 in 1944 to 912,000 in 1990 mostly due to the arrival of immigrants from other Soviet republics. The main task of the housing policy at that time was to meet the demand for apartments. Construction of industrial large scale buildings was acknowledged as the most progressive form of satisfying the aforementioned requirements. The residential houses were produced in several block house construction factories in Riga [18].

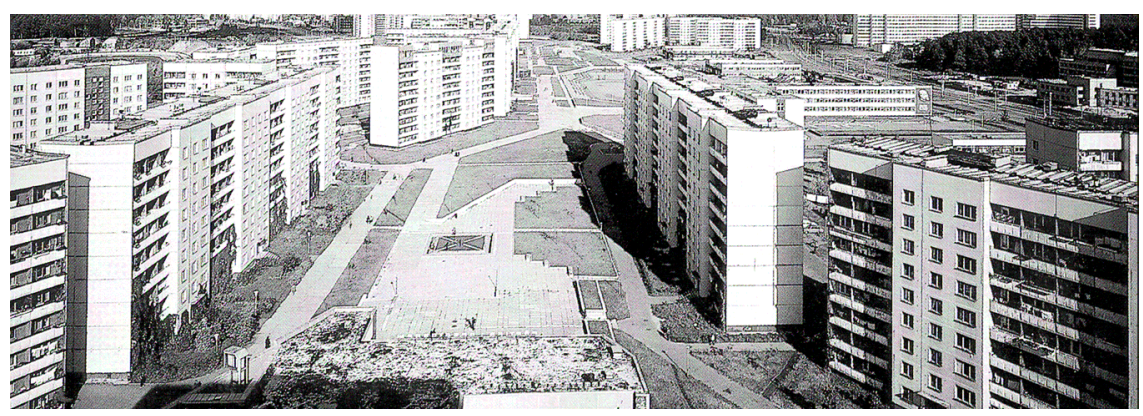

Figure 1: Pedestrian street and nine storey block houses in Soviet era Mezciems [19].

The neighbourhood of Mezciems is one of the large scale block house areas in Riga built during the period from 1975-1986. Mezciems is located 6km east of the centre of Riga. The northern part of Mezciems was added to the territory of Riga City in 1934 while the southern part followed in 1974. The development of Soviet era Mezciems can be divided into two periods - during the first period block houses with five, nine and sixteen storeys were built in the northern part of Mezciems in a space between single family houses, while during the second period, a green space was transformed into residential area with nine and sixteen storey block houses. The southern part of Mezciems is the one that depicts (or 
should depict) the ideals of Soviet micro-neighbourhood, because it was planned as one, conceptually completed territory, based on the Soviet conceptions about urban planning. Next to the residential area, a large hospital complex was built from 1974-1982.

Unlike the previous perimetric planning experience wherein block houses were located in squares, in Mezciems micro-neighbourhood a tendency to resign from mechanical planning appeared. The result was a free planning principle according to which "the traditional hierarchical notions which defined space, such as a street and a courtyard, disappeared, to be replaced by a democratic notion of buildings standing equally freely amidst greenery" [20]. It was intended to diversify the residential environment of Mezciems by planning lower structures, higher structures and accents.

Mezciems neighbourhood can be captured as a confined spatial unit whose area, population size and buildings do not exceed the quantity characterized by human potential to perceive space as a unitary entirety. This area at least theoretically gives an opportunity to identify oneself with it.

There are wide recreation facilities available in Mezciems - two parts of Mezciems residential area are enclosed by forests and there are four lakes located in Mezciems district.

\subsection{The detail plan of Mezciems - the planned spaces and functions}

The main principle of Mezciems plan was that a large and wide space for pedestrians, located in the middle of the area, links the maintenance objects, int. al., public and culture objects, located in the northern and southern parts of the micro-neighbourhood. Residential houses, schools and kindergartens are positioned around this pedestrian area. Thus, it is possible to reach all the necessary daily services within a few minutes' walk without the need to cross any street.

In Mezciems, as in other micro-neighbourhoods in Riga, during the planning process, the volume and exposure of services was calculated optimally and planned for a specific amount of residents [16]. Consequently, 15000 places of residence were planned in Mezciems. In order to provide all residents with the necessary services, five kindergartens, a school, a leisure centre, a polyclinic for children, a pharmacy, four shops, a cafe, a public-utility establishment, int. al., a hairdresser's, a garment and footwear repair outlet, a washhouse, a drycleaner's), a house manager's and a lift repair office [21] were built in Mezciems microneighbourhood.

The next step after the detail plan was the development of the individual house plan. During this stage, the detail plan could be changed, e.g., the entrances of residential houses could be increased in order to reduce the expenses of the buildings etc. In Mezciems the individual plans of houses were adapted to meet the needs of specific groups of residents - the ground floor was intended for large families; therefore, flats with five rooms were planned in them while in the upper floor studios for artists with large windows were planned [22]. Thus with the help of individual house plans, the structure of residents was partly defined. 


\subsection{The result of Mezciems construction}

Since Soviet era Mezciems was planned in a green area where there used to be meadows and a pasture through which a small river used to flow, natural conditions still play a vital role in this territory. During construction, the natural water course was damaged - the river was filled up and the water still has nowhere to go. Therefore, there are practical housing problems including cracked walls and shifting soil.

As the money was provided for the construction of a specific building not for the development of whole micro-neighbourhood, a situation often arose whereby not all of the planned services and houses were built. Most often, public, social and culture objects were the ones that were left unbuilt. This is also the case of Mezciems. In 1990, it was admitted that, based on the normatives, missing or inadequate establishments and services in Mezciems include a comprehensive school, rooms for out-of-school activities, an outpatients clinic, a gym, a sports hall, a swimming pool, a dance floor, a culture centre, a cinema, a library, shops, a marketplace, a public catering place, a laundry, a bathhouse, a savings bank department, law advice bureau, public toilets and fire-station. As all these services were missing, it was predicted that some of them will be provided by adjoining neighbourhoods.

As the public centres were only partly built in Mezciems, the central pedestrian space in Mezciems residential area is partly deprived of its role. This territory is accessible for pedestrians, but it leads nowhere [22]. There was also an intention to create a park, but it never to fruition. Mezciems, counter to the intended ideals, where everything the residents need in their daily life is available, has turned out to be a large scale multi-storey block house area with some shops, kindergartens, two schools and a hospital.

\section{The spaces of Mezciems residents' daily activities}

Since the collapse of Soviet Union, spatial changes have occurred in Mezciems. In the surrounding areas - former meadows, new residential areas have been built. Many of the services with a public and social function have disappeared. They have mostly been replaced by shops with coherent functions: "I walk a lot. I have walked criss-cross across the whole micro-neighbourhood. Everything is like it used to be; just some shops have been built. And new residential areas. Yes, and our houses have become older, have deteriorated", said a respondent from Mezciems.

Mezciems nowadays is one of Riga's' "bedrooms", where most residents spend their evenings, nights and weekends, therefore their activity space is located around their place of residence, shops and public transport stops: "I come home from work and walk from trolleybus stop home. If I need something, I go into a shop. Where else could I go? I have no dog, my kids have grown up, and they can get everywhere they need themselves". As one more significant activity space in Mezciems, natural resources appear - forest and the Lake District. These are used for recreation - in winter for walking and skiing, in summer for 
walking, running or cycling: "We often go to the forest. In summer we sometimes cycle. The lake is just next to our house. When I had a birthday, we made a picnic by our lake", explained another respondent.

The influence of lifestyle appears in the attitude of the interviewed residents towards the activity opportunities provided in Mezciems. Respondents who spend only evenings, nights and holidays (I will call them daily commuters) in Mezciems stress the restful atmosphere and the sufficiency of available services: "I am glad to be living in Mezciems, because it is possible go to the forest, public transport is close and shopping opportunities are very good. The district is safe and silent". However, needless to say, not all residents leave Mezciems in their daily life. There are specific groups of people who spend both week days and weekends in the micro-neighbourhood - small kids and their mothers, some pupils, pensioners, the unemployed and representatives of specific professions, e.g., shop assistants, hospital and leisure centre employees etc. A street sweeper, who spends every day in Mezciems, admitted that: "People come here; sleep and then they go back to work. And again to sleep and to work. There is nothing to do here - no theatre and no movies. There are only shops here. And residential buildings". Likewise, a pensioner who has lived in Mezciems for eight years admitted that: "We pensioners have no place to meet here - no room, where we could come together and talk (...)". It means that, in contrast to daily commuters who can perform their sports, culture and other activities in other places in Riga, persons who stay in Mezciems more or less all the time, feel discomfort and a necessity for them.

Between the two groups of residents, characterized by different lifestyles, a diverse attitude towards the distance to the nearest social, culture and sports activity places can be observed. Those daily commuters interviewed mentioned its close proximity to the city centre as an important advantage of Mezciems micro-neighbourhood: "Public transport goes very often - it is possible to get to the centre in 25 minutes from any place in the micro-neighbourhood". The nearest cinema is "located rather close - 40 minutes on foot, through the forest. I have walked to the cafés or cinema a few times at weekends", mentioned a lady daily commuter I interviewed. Whereas persons, who spend their daily lives in Mezciems, consider the distance to the nearest social and cultural services in other neighbourhoods and to the city centre to be too long to overcome it on a daily basis. Most probably, the diverse attitudes towards space and distance could depend upon different relocation and daily migration habits within the urban space.

If a diverse attitude can be noted in relation to the activity opportunities provided in the micro-neighbourhood, then no differences appear among respondents, when talking about their attitude towards the social environment in Mezciems which was investigated through their feelings in space. The area surrounding their homes is appreciated as a better one, than the area further away - figure 2 shows that areas closer to respondents' place of residence are valued more highly (more respondents have coloured it as a safe area, where they spend their time willingly). It means that apart from location, respondents feel good in 

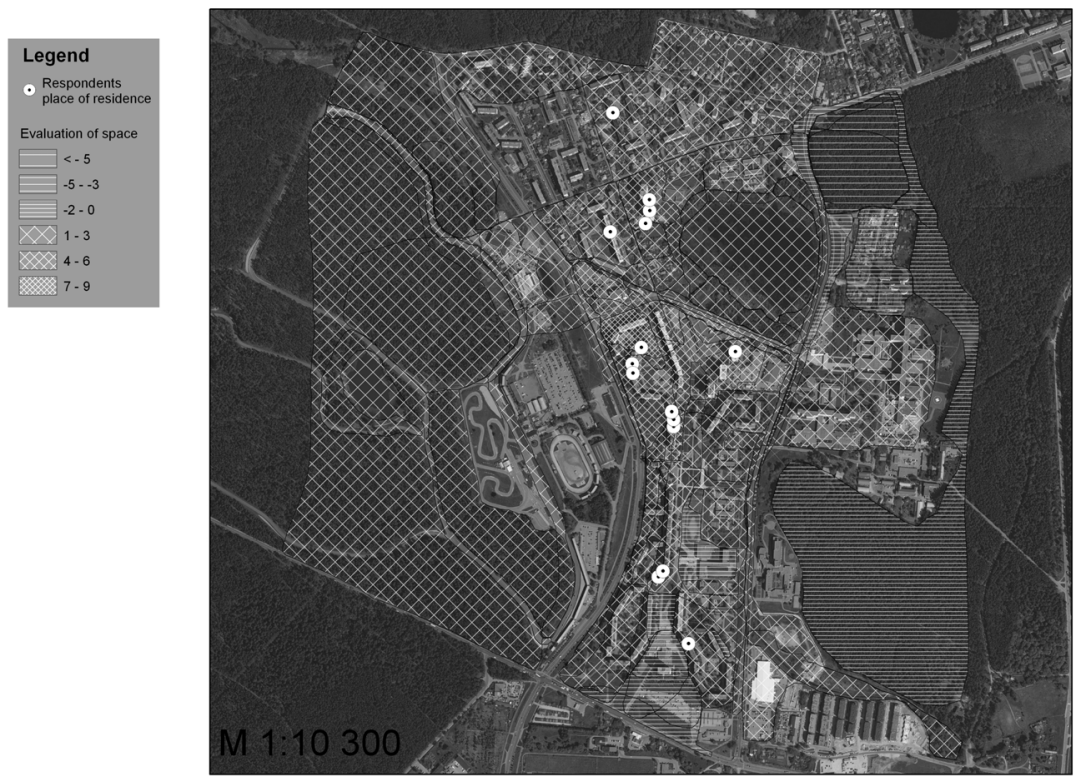

Figure 2: Respondents' attitude towards space in Mezciems microneighbourhood.

territories close to their homes. As a space where respondents feel good, the space they use for walks appears - along the streets, along roads in forest located in the western part of micro-neighbourhood. The fact that these areas are preferred by residents rather than the space between residential buildings planned for pedestrians during the Soviet era is affirmed by one of the respondents: "There are cars parked everywhere - by houses, between houses, especially in the evenings, when people have all come home. Then, if I want to blow the cobwebs away, I go to the forest. Or walk back and forth along Eizensteina Street. Other people also walk there, I already know them by face".

The unsafe territory marked by respondents is located in the forest corner next to an abandoned building in north-east part of Mezciems. This building was planned as a maternity house in the late 1980's, but was never finished. The fact that this territory appears to be the most unsafe is confirmed by data obtained during the interviews. A couple of respondents mentioned that as there is no place for teenagers (where they can meet, talk, rest, do their activities etc.) in the micro-neighbourhood, they spend their free time in the unfinished abandoned building: "They climb into that house, I don't know to which floor - high. They drink there and bluster. I have called the police a few times to take them awaythey are still teens, can fall down...anything can happen to them". Likewise, a territory mentioned by respondents as being unsafe is the forest territory next to the unfinished maternity house. As an inhabitant mentioned in an interview: "Once I was watching the TV and heard that there, next to the last bus stop, where that forest is - is the place where those indecorous ones walk. I didn't 
know that. When my granddaughter wasn't in school yet, we used to go for a walk there".

While exploring a series of maps drawn by residents, it revealed that public objects associated with danger include shops and public transport stops. A territory like this - around and behind a shop is located in the southern part of Mezciems (figure 2). This territory was coloured in as unsafe by a couple of respondents. In the Soviet era detail plan of Mezciems micro-neighbourhood, this territory was intended to be one of the public centres.

The large scale block house area of Mezciems with its untidy, non-verdant and tatty environment, cars in all the free spaces and few official parking places in the courtyards of residential houses does not seem to be a friendly place for people. The landscape is drab and homogeneous, though the residents interviewed did not mention it as a deficiency of the neighbourhood or a factor that would bother them. Objects the respondents mentioned that they would like to change in the neighbourhood in regard to the environment include easily changeable things - cutting the grass, collecting the garbage in both the territory between buildings and in the forest and the renewal of kids' playgrounds. The aforementioned activities are connected to some initiatives of residents for the improvement of their residential area: "I undertook it a few times... when I went for a walk with my dog; I took my gloves with me and collected all these papers and other garbage. But it's useless. The next day everything looks the same. I gave up (...)". As it appears in the quote, the initiative of one person cannot change the environment and attitude. Even if residents long for a tidier environment, they are not ready to take part in the transformation: "There are very few initiatives coming from residents that could raise interest among other residents to take part in joint work organization" admitted one Mezciems resident interviewed. The attitude of the majority seems like a legacy of the Soviet era when everything was planned and done for people instead of by them, and when people did not have to and even were no allowed to take part in the development of their residential environment.

Mezciems is also characterized by individual isolation - residents do not know their neighbours well, they do not communicate with one other. This aspect showed up as a fact, not a problem among the respondents.

\section{Conclusions}

Mezciems was planned to be not only a residential area with residential buildings, but a neighbourhood with all services needed in daily life, as well as opportunities to carry out different activities. But it was never implemented. As often occurred in Soviet era micro-neighbourhoods, in Mezciems buildings intended for social, cultural and sports activities were never built.

The activity spaces of Mezciems residents are concentrated around their places of residence, shops, public transport stops and recreation spaces. An opportunity to rest in fresh air and specific borders of Mezciems are features that distinguish Mezciems from other post-Soviet neighbourhoods - Mezciems is a very green neighbourhood, enclosed by forests from two sides. 
Forest as an activity space in the view of residents is characterized by two contrary features - the forest on the western side of the residential area is related with positive emotions, while on the eastern side, the forest is considered to be an unsafe place, where it is better not to loiter due to the social groups using this space.

It is possible to divide the attitude of resident towards the functions available to them in Mezciems into two groups due to the different lifestyles that characterize each group. Interviewed people who spend their days (working, studying, etc.) in other neighbourhoods of Riga, are pleased with the functions and services in Mezciems and talk of this micro-neighbourhood as a green and safe area. Whereas those interviewed residents who spend more or less all their life in Mezciems, need something more than just shops and forest. A necessity for the planned but not realized public and culture centre in microneighbourhood appears in the respondents' negative attitude towards the environment of the residential area characterised by easy changeable things. Such factors as the amount of storeys or flats in one staircase, the size of buildings, and monotony of landscape residents are not considered; residents take them for granted.

\section{References}

[1] Sullivan, W., Kuo, F.E., Depooter S., The Fruit of urban nature: vital neighborhood spaces. Environment and Behaviour, 36(5), pp. 678-700, 2004.

[2] Bonaiuto, M., Bonnes, M., Continisio, M. , Neighborhood evaluation within a multiplace perspective on urban activities. Environment and Behavior, 36(1), pp. 41-69, 2004.

[3] Appleyard, D., Livable streets: protected neighborhoods? Annals of the American Academy of Political and Social Science, 451, pp. 106-117, 1980.

[4] Kuo, F.E., Bacaicoa, M., Sullivan, W.C., Transforming inner-city landscapes. Environment and Behaviour, 30(1), pp. 28-59, 1998.

[5] Hur, M. \& Jones, H.M., Factors that influence residents' satisfaction with neighbourhoods. Environment and Behavior, 40(5), pp. 619-635, 2008.

[6] Shaw, D.T.B., Planning Leningrad. Geographical Review, 68(2), pp. 183200, 1978.

[7] Bunkse, E.V., The role of a humane environment in Soviet urban planning. Geographical Review, 69 (4), pp. 379-394, 1979.

[8] Nechemias, C., The Impact of Soviet housing policy on housing conditions in Soviet cities: the uneven push from Moscow. Urban Studies 18(1), pp. 18, 1981.

[9] Filipovic, M., Influences on the sense of neighborhood: case of Slovenia. Urban Affairs Review, 43 (5), pp. 718-732, 2008.

[10] Gentile, M. \& Tammaru, T., Housing and ethnicity in the Post-Soviet city: Ust'-Kamenogorsk, Kazakhstan. Urban Studies, 43(10), pp. 1757-1778, 2006. 
[11] Ceccato, V., Crime in a city in transition: the case of Tallinn, Estonia. Urban Studies, 46 (8), pp. 1611-1638, 2009.

[12] Burgmanis, G., Youth in shadow of economic crisis: juvenile delinquency in Riga neighbourhoods Tiltai. Priedas: Mokslo darbai, 39, pp. 364-372, 2009.

[13] Grava, S., The urban heritage of the Soviet regime: the case of Riga, Latvia. Journal of the American Planning Association 59 (1), pp. 9-30, 1993.

[14] Smith, D.S., The Socialist city (Chapter 3). Cities After Socialism: Urban and Regional Change and Conflict in Post-Socialist Societies, eds. G., Andrusz, M., Harloe \& I. Szelenyi, Blackwell Publishers: Oxford and Cambridge, pp. 70-100, 1996.

[15] Underhill, J.A., Soviet new towns, planning and national urban policy: shaping the face of Soviet cities. The Town Planning Review, 6(3), pp. 263285, 1990.

[16] Millers, I. Personal communication, 23 November 2009, Spatial planner of Mezciems district, Riga, Latvia.

[17] Строительные нормы и правила. Градостроительство. Планировка и застройка городских и сельских поселений. СНиП 2.07.01-89., Москва, 1989.

[18] Treija, S. \& Bratuškins, U., Lielmēroga dzīvojamo rajonu attīstības problēmas Rīgā. Arhitektūra un būvzinātne: RTU Zinātniskie raksti 2(4), 77.-83.lpp., 2003.

[19] Berglund, U., Privatisation, Segregation and Local Engagement: A Latvian Case Study. http://cibworld.xs4all.nl/dl/publications/Pub281/04Chapter2.pdf

[20] Grzinic, M., Jurica, I., Marjanovic, I., Intro Reading into the Seminar Writing Central European Art History. www.antville.org/static//files /INTROWRITINGbakos-1.doc

[21] Sociālās infrastruktūras aplēses Rīgas dzīvojamos rajonos. Латгипрогорстрой, 1990.

[22] Juhnevica, G. Personal communication, 25 November 2009, The director of Mezciems house-manager's office 1991-2004, Riga, Latvia. 